\section{Controlled-release Fertilizer Type and Rate Affect Landscape Establishment of Seven Herbaceous Perennials}

\author{
Yan Chen ${ }^{1}$, Regina P. Bracy, Allen D. Owings, \\ and Joey P. Quebedeaux
}

\begin{abstract}
AdDitional INDEX wORDs. Osmocote ${ }^{\circledR P l u s, ~ t a b l e t ~ f e r t i l i z e r, ~ C u p h e a ~ i g n e a, ~}$ Cuphea byssopifolia, Echinacea purpurea, Gaura lindbeimeri, Hemerocallis, Lantana camara, Rudbeckia fulgida
\end{abstract}

SUMmARY. Use of controlled-release fertilizers (CRF) has been recommended to the landscape service industry as a best management practice for establishing landscape plants. However, application practices vary considerably among professionals and recommendations are lacking for the appropriate type (tablet vs. granular), application rate, and timing of CRF to establish herbaceous perennials. In this study, cigar plant (Cuphea ignea), daylily (Hemerocallis 'Stella de Oro'), gaura (Gaura lindheimeri 'Siskiyou Pink'), lantana (Lantana camara 'New Gold'), mexican heather (Cuphea byssopifolia), purple coneflower (Echinacea purpurea), and rudbeckia (Rudbeckia fulgida 'Goldsturm') were fertilized with granular CRF (GF) $15 \mathrm{~N}-3.9 \mathrm{P}-10 \mathrm{~K}$ ( 8 to 9 month) at $0,1,2$, or $4 \mathrm{lb} / 1000 \mathrm{ft}^{2}$ nitrogen $(\mathrm{N})$ at transplant (no fertilization, GF1, GF2, and GF4, respectively), a split application of GF with $1 \mathrm{lb} / 1000 \mathrm{ft}^{2} \mathrm{~N}$ applied at transplant and $1 \mathrm{lb} / 1000 \mathrm{ft}^{2} \mathrm{~N}$ applied 5-months later (GF2-split), or tablet CRF 16N-3.5P-10K (8 to 9 months) at two tablets per plant $(7.5 \mathrm{~g})$ at transplant (TF2). Plant size and visual quality (VQ) at 5 months after transplant (MAT) were improved by fertilization for all perennials except 'Stella de Oro' daylily. Compared to GF2, GF4 improved the growth of perennials of larger size and greater biomass production (i.e., cigar plant), but did not further improve their VQ. All perennials grown with TF2 had similar size and quality as those grown with GF2 at 5 MAT. At 15 MAT, no difference was found among fertilizer treatments for surviving perennials except cigar plant. Split application (GF2-split) did not improve overwinter survival or second-year plant growth and quality for most species when compared with GF2. On the basis of these results, we recommend applying two tablets $(7.5 \mathrm{~g})$ of $16 \mathrm{~N}-3.5 \mathrm{P}-10 \mathrm{~K}$ per plant at transplant to establish the perennials tested in this study.

$\mathrm{U}$ se of slow-release fertilizers or CRF is being recommended to the landscape service industry as a best management practice (Florida Yards \& Neighborhoods, 2006; Louisiana Yards \& Neighborhoods, 2007). Benefits of using CRF include improved nutrient use efficiency (Alva, 1992; Juntunen et al., 2003) and minimized N leaching (Broschat, 1995; Cox, 1993; Shaviv and Mikkelsen, 1993 ). However, research needed to make appropriate recommendations for CRF use in the landscape has not been completed (Shober et al., 2010).

\footnotetext{
This research was supported by the Louisiana Agricultural Experiment Station. Trade names mentioned in this manuscript do not imply product endorsement by the authors and their associated institution. We thank Southwest Perennials (Houston, TX) and Scotts Miracle-Gro (Marysville, $\mathrm{OH}$ ) for plant and fertilizer donations.

Louisiana State University Agricultural Center, Hammond Research Station, 21549 Old Covington Highway, Hammond, LA 70403

${ }^{1}$ Corresponding author. E-mail: yachen@agcenter. lsu.edu.
}

Although extensive literature has been published on CRF application technology for container-grown nursery plants (Cabrera and Pemberton, 2007; Klock-Moore and Broschat, 1999; Yeager et al., 1980), results from these studies bear little relevance to landscape application. Most landscape fertility studies have focused on nutrient requirements of woody species (Gilman and Yeager, 1990; Gilman et al., 2000; Torres, 1987) or palms [Arecaceae (Broschat, 2001)]. Few studies have investigated the nutrient requirements of herbaceous perennials and the possibility of grouping them by their nutrient requirements during landscape establishment (Proctor et al., 2004; Strother et al., 2002). Nitrogen recommendations for establishing herbaceous perennials in the southeastern states vary from 1 to $6 \mathrm{lb} / 1000 \mathrm{ft}^{2} /$ year (Brown, 2007; Kelly and Newman, 2007; Kessler et al., 2002).

Osmocote ${ }^{\circledR}$ Plus (Scotts, Marysville, $\mathrm{OH}$ ) is one of the CRF being used by the green industry (Beverly et al., 1997; Greenwell, 1982; Neal, 2003). Tabletform Osmocote ${ }^{\circledR}$ Plus is manufactured using the same coating technology as the granular form (Smaal, 1984). Tablet fertilizers were designed for orchard trees and later used in field production of nursery plants (Gray and Rose, 1968). The advantages of using tablets over granular CRF include easier dosing and more uniform application (Ingram and Yeager, 1985). In addition, use of tablets may alleviate the competition between target plants and surrounding vegetation, a problem associated with broadcasting granular fertilizers (Jacobs et al., 2005).

Shober et al. (2010) has reported that recommendations for fertilization timing for nonwoody plants are lacking. Recommendations vary among the few published research studies (Proctor et al., 2004; Shober et al., 2010). A survey of Florida landscape contractors indicated that $46 \%$ of participants applied fertilizer to ornamental plants three or more times per year (Israel et al., 1995). A similar survey in Louisiana found that $50 \%$ of participants fertilized ornamental plants in the spring and $27 \%$ fertilized in the spring and fall (Y. Chen, A.D. Owings, and R. Bracy, unpublished data). Splitting the recommended application rates into smaller amounts over the course of a growing season has been recommended for container- and field-grown woody ornamental plants (Halbrooks, 1990; Rose, 1999) as is fertilizing in late summer or early fall (Halbrooks, 1990; Kuhns, 1987).

\begin{tabular}{llll}
\hline $\begin{array}{l}\text { Units } \\
\text { To convert U.S. to SI, } \\
\text { multiply by }\end{array}$ & U.S. unit & SI unit & $\begin{array}{l}\text { To convert SI to U.S., } \\
\text { multiply by }\end{array}$ \\
\hline 0.3048 & $\mathrm{ft}$ & $\mathrm{m}$ & 3.2808 \\
2.54 & inch $(\mathrm{es})$ & $\mathrm{cm}$ & 0.3937 \\
48.8243 & $\mathrm{lb} / 1000 \mathrm{ft}^{2}$ & $\mathrm{~kg} \cdot \mathrm{ha}^{-1}$ & 0.0205 \\
28.3495 & $\mathrm{oz}$ & $\mathrm{g}$ & 0.0353 \\
1 & $\mathrm{ppm}$ & $\mathrm{mg} \cdot \mathrm{L}^{-1}$ & 1 \\
$\left({ }^{\circ} \mathrm{F}-32\right) \div 1.8$ & ${ }^{\circ} \mathrm{F}$ & ${ }^{\circ} \mathrm{C}$ & $\left(1.8 \times{ }^{\circ} \mathrm{C}\right)+32$ \\
& & &
\end{tabular}


The objective of this study was to determine optimum CRF recommendations including fertilizer type (tablet vs. granular), rate, and timing for establishing commonly used herbaceous perennials in an amended landscape bed. The seven perennials selected for this study have distinct growth patterns and different plant sizes at maturity. Cigar plant, mexican heather, and lantana have semiwoody branching stems with flowers on the ends of smaller branches; whereas daylily, rudbeckia, purple coneflower, and gaura are herbaceous and clump forming with flowers on slender stems (rudbeckia and purple coneflower), spikes (gaura), or scapes (daylily) (Brown, 1976; Odenwald and Turner, 2006). These perennials were selected with the intention of comparing their nutritional needs and determining whether they can be grouped by size or growth pattern for fertilization practice.

\section{Materials and methods}

EXPERIMENTAL DESIGN. This experiment was conducted at the Louisiana State University Agricultural Center (LSUAC) Hammond Research Station, Hammond, LA (lat. $30^{\circ} 32^{\prime} \mathrm{N}$, long. $\left.91^{\circ} 9^{\prime} \mathrm{W}\right)$. The experiment had six fertilizer treatments $\times$ seven perennial species arranged in a randomized complete block design with four blocks. A total of 24 field plots [each 10-ft long (north to south) $\times 8$-ft wide] were arranged in three raised beds [each $100-\mathrm{ft}$ long (west to east) $\times 10-\mathrm{ft}$ wide]. Each raised bed contained eight plots with a 4 -ft-wide buffer zone between each plot. Four blocks, each containing six plots, were arranged along the drainage grade $(2 \%)$ running from west to east. Fertilizer treatments were randomly assigned to the plots within each block.

Bed PReparation. Before the study, the native topsoil had $56 \%$ sand, $31 \%$ silt, and $13 \%$ clay with $1 \%$ organic matter. Soil analysis indicated the following nutrients (in milligrams per liter): 37 phosphorus (P), 53 potassium (K), 499 calcium (Ca), and 127 magnesium (Mg) (LSUAC Soil Testing and Plant Analysis Laboratory, Baton Rouge, LA). The native soil $\mathrm{pH}$ was 5.3. The site was sprayed with glyphosate (Roundup Pro Concentrate; Monsanto, St. Louis, MO) to eliminate vegetation. Dolomitic limestone was broadcast applied at $70 \mathrm{lb} /$
$1000 \mathrm{ft}^{2}$ as indicated by soil analysis to raise soil $\mathrm{pH}$ to 6.5 . A 2 -inch-thick layer of pine bark was incorporated with the limestone into the top 6 inches of soil. Adding pine bark to make raised beds is a common practice by landscape professionals. Pine bark was 6 -month old with particle size from $3 / 8$ to $5 / 8$ inch.

Treatments. Four-inch pots of cigar plant, 'Stella de Oro' daylily, 'Siskiyou Pink' gaura, 'New Gold' lantana, mexican heather, purple coneflower, and 'Goldsturm' rudbeckia were transplanted to field plots 20 Mar. 2005. Three daylilies and two plants each of the other species were randomly arranged in each plot with like species planted next to each other. Plants were spaced 30 inches on centers. Two CRF were used: GF Osmocote ${ }^{\circledR}$ Plus $15 \mathrm{~N}-3.9 \mathrm{P}-10 \mathrm{~K}$ (7\% ammoniacal and $8 \%$ nitrate nitrogen) and TF Osmocote ${ }^{\circledR}$ Plus $16 \mathrm{~N}-3.5 \mathrm{P}-$ $10 \mathrm{~K} 7.5 \mathrm{~g}(7.5 \%$ ammoniacal and $8.5 \%$ nitrate nitrogen). Both have projected longevities of 8 to 9 month at $70{ }^{\circ} \mathrm{F}$. Manufacturer's recommended application rates are 2 to $6 \mathrm{lb} /$ $1000 \mathrm{ft}^{2} \mathrm{~N}$ of GF or two to three tablets per plant of TF. Six fertilizer treatments included no fertilization, GF at 1,2 , or $4 \mathrm{lb} / 1000 \mathrm{ft}^{2} \mathrm{~N}$ at transplant (GF1, GF2, GF4, respectively); GF at $2 \mathrm{lb} / 1000 \mathrm{ft}^{2} \mathrm{~N}$ split with $1 \mathrm{lb} / 1000 \mathrm{ft}^{2} \mathrm{~N}$ applied at transplant and $\mathrm{l} \mathrm{lb} / 1000 \mathrm{ft}^{2} \mathrm{~N}$ applied 5 months later on 24 Aug. 2005 (GF2split); and TF applied at TF2. The low rate, GFl provided similar $\mathrm{N}, \mathrm{P}$, and $\mathrm{K}$ as TF2 in this study $(36,9.5$, and $22.3 \mathrm{~g} / \mathrm{plot}$; and $36,7.5$, and $20.7 \mathrm{~g} /$ plot, respectively). Granular fertilizer was applied by a hand-push spreader (24H12; Gandy, Owatonna, MN) and incorporated into the top soil by a hand-held cultivator (GT3070; Corona Clipper, Corona, CA). The second application of GF2-split in August was top dressed without incorporation. Tablet fertilizer was applied by placing two tablets on opposite sides at the bottom of the planting hole before planting.

Bed maintenance. Plots were watered with microsprayer sprinklers (Vari-Jet; Antelco, Longwood, FL) that provided 0.5 -inch water per irrigation. Irrigation frequency was once every other day for the first 4 weeks after planting and twice per week thereafter. Irrigation was automatically postponed by rain sensor after
0.5 -inch rainfall events. Irrigation was reduced to once per week from $26 \mathrm{Aug}$. through 30 Nov. 2005. The total rain event precipitation from April through September at this site was 28.9 inches (LSUAC Louisiana Agriclimatic Information System, 2005). Irrigation was suspended on 1 Dec. 2005 and resumed on 15 Feb. 2006 at once per week and increased to twice per week from 26 Apr. 2006 until the experiment was ended.

Data collection. Plants were evaluated for size and VQ at 1,5 , and 15 MAT (22 Apr. 2005, 24 Aug. 2005, and 22 June 2006, respectively). Size index (SI) was calculated as $\left(\mathrm{H}+\mathrm{W}_{1}+\mathrm{W}_{2}\right) / 3$, where $\mathrm{H}$ is the plant height measured from the soil surface to the tallest point of the plant, $\mathrm{W}_{1}$ is the widest width, and $\mathrm{W}_{2}$ is the width perpendicular to the widest width. Overall plant VQ was assessed with ratings on a scale from 1 to 10 after taking consideration of plant size, foliage color and density, and flowering performance. Ratings from 8 to 10 indicated good to excellent quality. Ratings of 6 or 7 indicated average quality that would be acceptable for moderately maintained landscape beds. Plants that received ratings below 6 were considered unacceptable. Dead plants received a rating of 1. Two teams of horticulturists rated every plant independently at each sample date. Because no interaction was found between team and sample date, data were pooled before analysis.

Relative leaf chlorophyll content was measured at $\mathrm{l}$ and 5 MAT using a Minolta SPAD-502 m (Spectrum Technologies, Plainfield, IL). SPAD meters determine the relative amount of chlorophyll by measuring the transmittance of the leaf to light at wavelength 600 to $700 \mathrm{~nm}$ and 400 to $500 \mathrm{~nm}$. Readings were taken from every plant by randomly selecting five youngest, fully expanded leaves from a plant and taking three readings per leaf. The final SPAD meter reading of a plant was the average of 15 readings.

Flowering performance during the 2005 growing season was determined by number of flowers for daylily, purple coneflower, and rudbeckia, by number of inflorescences for gaura, and by flower quality rating (FQ) for cigar plant, mexican heather, and lantana. Daylily flowers, defined as outer petals being partially reflexed, were counted every 2 weeks from 22 Apr. 
to 23 June on six sample dates and presented as total number of flowers. Flowers of rudbeckia and purple coneflower, defined as all ray flowers being unfurled and the disk being exposed, were counted from 10 July to 24 Aug. on four sample dates and presented as total numbers of flowers. Gaura inflorescences (flower spikes) with any open flowers were counted on 24 Aug. Cigar plant, mexican heather, and lantana were rated for flowering performance on 22 Aug. using a scale from 1 (no flowers) to 5 (abundant flowers).

One plant of each species from each plot was destructively sampled at 5 MAT. The aboveground parts of the plants were dried at $70{ }^{\circ} \mathrm{C}$ for $48 \mathrm{~h}$. Leaf tissue samples were collected from the youngest fully expanded leaves, washed, dried, and then ground in a stainless-steel Wiley mill. Dry weight (DW) of leaf tissue samples was added to the rest of shoot samples to determine shoots DW. Leaf tissue analyses were conducted by the LSUAC Soil Testing and Plant Analysis Laboratory (Baton Rouge). Leaf tissue $\mathrm{N}$ was determined by dry combustion using a carbon-N analyzer (TruSpec; LECO, St. Joseph, MI), and $\mathrm{P}, \mathrm{K}, \mathrm{Ca}$, and $\mathrm{Mg}$ were determined by inductively coupled plasma emission spectroscopy (Fisons Instruments, Dearborn, MI).

The remaining plants in the plots were evaluated on 22 June 2006 for overwinter survival. The successfully overwintered plants (plants showing new growth) were counted and overwinter survival rate reported as percentage of total plants. Plants were also measured for SI and rated for VQ.

STATISTICAL analysis. Data were subjected to analysis of variance using the mixed procedure of SAS (version 9.1; SAS Institute, Cary, NC). Tukey's significant difference test at $P<0.05$ was used to separate means. Ordinary linear regression models (PROC REG) were used to determine the response of SI, DW, and leaf tissue $\mathrm{N}$ concentration to GF rates. Exact logistic regression (PROC LOGISTIC) was used to analyze the overwinter survival rate.

\section{Results and discussion}

FIRST-YeAR PLANT GROWTH. POSitive linear responses to GF rates were found in SI for all species except daylily at 1 and 5 MAT [Fig. I (1MAT data not shown)]. The lack of response by daylily to fertilization is

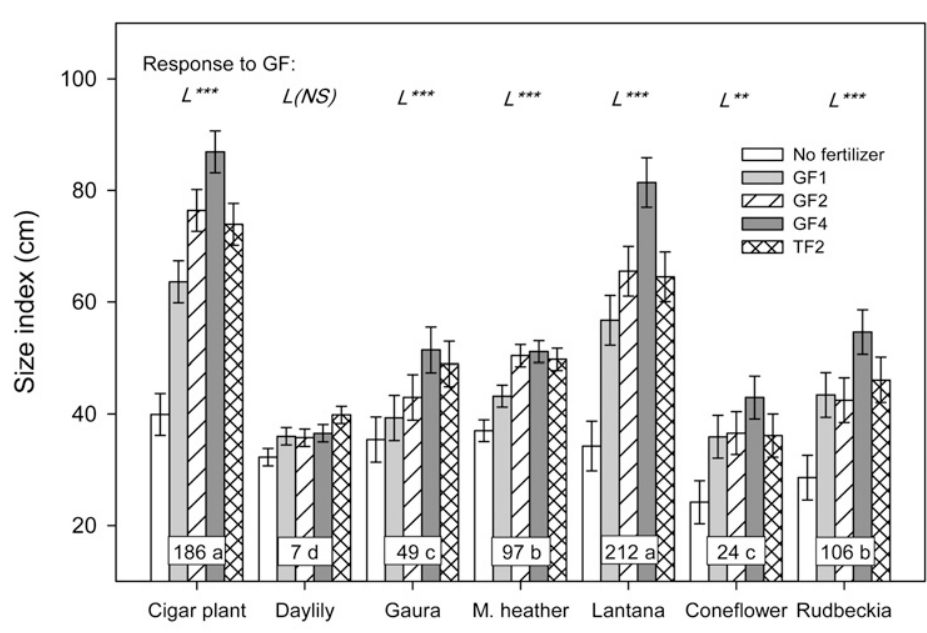

Herbaceous pernnials

Fig. 1. Size index (SI) of seven herbaceous perennials at $\mathbf{5}$ months after transplant into the landscape. Plants were fertilized with granular controlled-release fertilizer (GF) $15 \mathrm{~N}-3.9 \mathrm{P}-10 \mathrm{~K}$ at $0,1,2$, and $4 \mathrm{lb} / 1000 \mathrm{ft}^{2}$ nitrogen [no fertilizer, GFl, GF2, and GF4 $\left.\left(1 \mathrm{lb} / 1000 \mathrm{ft}^{2}=48.8243 \mathrm{~kg} \cdot \mathrm{ha}^{-1}\right)\right]$ or tablet fertilizer $16 \mathrm{~N}-3.5 \mathrm{P}-$ $10 \mathrm{~K}[7.5 \mathrm{~g}(0.265 \mathrm{oz})]$ at two tablets per plant $(\mathrm{TF} 2) . \mathrm{SI}=($ plant height + widest width + perpendicular width)/3. Linear effects of GF rates on each perennial were tested via ordinary linear regression models using PROC REG of SAS with randomized complete block design $\left({ }^{*}, * *\right.$, and ${ }^{* * *}$ indicate significance at the 0.05 , 0.01 , or 0.001 level, respectively). Bars represent the least significant difference values $(\alpha=0.05)$ for pair-wise comparison of fertilizer treatments within each perennial. Values superimposed on each perennial are mean dry weight (grams) averaged over fertilizer treatments. Values followed by the same letter are not significantly different using Tukey's significant difference test at $\alpha=0.05 ; \mathrm{M}$. heather $=$ mexican heather, $1 \mathrm{~cm}=0.3937 \mathrm{inch}, 1 \mathrm{~g}=0.0353 \mathrm{oz}$.

similar to that reported for iris [Iris siberica 'Caesar's Brother' (Proctor et al., 2004)]. A limited response was reported for switchgrass (Panicum virgatum 'Shenandoah') and sedum (Sedum telephium 'Herbstfreude') during landscape establishment in a Cecil clay loam (Proctor et al., 2004). Despite possible low nutrient requirements by these species, a possible explanation for the lack of response is that plants such as daylily and iris are able to store nutrients in their roots (or in leaves such as sedum) and may establish with little or no supplemental fertilization.

Among responsive species, the highest SI was obtained with GF4 for cigar plant, lantana, and rudbeckia (Fig. 1). For gaura, mexican heather, and purple coneflower, GF4 resulted in similar growth as GF2. A trend observed with SI (as well as average DW) was that larger plants such as cigar plant and lantana responded more significantly to higher rate than smaller plants such as gaura and purple coneflower (Fig. 1). The TF2 treatment resulted in similar or greater SI as GF2 for all species, and similar SI as
GF4 for mexican heather, gaura, and purple coneflower (Fig. 1). Considering that TF2 only provided half of the $\mathrm{N}, \mathrm{P}$, and $\mathrm{K}$ as GF2 to a treatment plot, this treatment seemed to be more efficient than granular CRF in obtaining similar plant growth, especially for smaller perennials.

Tablet fertilizer was reported to promote the growth of pine tree species (Berry, 1983) and several nursery crops in field production (Hatchell and Marx, 1987). However, no previous studies have compared the effects of tablet vs. granular CRF on herbaceous perennials. One possible explanation for the growth response to TF observed in this study is that the placement of the tablets next to the root ball may have increased the availability of nutrients in the root zone. Sato and Morgan (2008) reported from a leaching column study with sandy soil that incorporating granular CRF (CitriBlen ${ }^{\circledR}$, Scotts) into soil media minimizes $\mathrm{N}$ loss due to volatilization. Specifically, CRF incorporation resulted in more than three times as much ammoniacal nitrogen $\left(\mathrm{NH}_{4}-\mathrm{N}\right)$ remaining in the soil compared with surface application. 
LEAF TISSUE NUTRIENTS. Linear responses to GF rates were found in leaf tissue $\mathrm{N}$ concentration for all species at 5 MAT (Fig. 2). Generally, all species fertilized with GF4 had higher leaf $\mathrm{N}$ concentrations than unfertilized plants (Fig. 2). Most species fertilized with GF1, GF2, and TF2 had similar leaf $\mathrm{N}$ concentrations as unfertilized plants except mexican heather and purple coneflower (Fig. 2 ). For daylily, because no growth response was found, the increases in leaf $\mathrm{N}$ concentration with GF4 and TF2 treatments indicate possible luxury $\mathrm{N}$ consumption (Fig. 2). For purple coneflower, leaf tissue $\mathrm{N}$ concentration was higher in plants receiving any fertilizer treatment compared with unfertilized plants (Fig. 2), the latter exhibiting $\mathrm{N}$ deficiency symptoms (small and spindly plants and lower leaf chlorosis). Except purple coneflower, all unfertilized perennials appeared healthy although leaf tissue $\mathrm{N}$ concentrations in unfertilized daylily, gaura, and mexican heather fell below the suggested sufficient range for herbaceous perennials $[2.2 \%$ to $3.2 \%$ (Barker and Bryson, 2007)]. Generally, TF2 resulted in similar leaf tissue $\mathrm{N}$ concentrations as GF2 and, in some cases, as GF4 (Fig. 2).
Fertilizer effects on leaf tissue P and $\mathrm{K}$ concentrations varied among species without significant trends. Generally, $\mathrm{P}$ and $\mathrm{K}$ concentrations in unfertilized plants were within the average ranges reported for healthy herbaceous perennials $[0.15 \%$ to $0.72 \%$ for $\mathrm{P}$ and $0.7 \%$ to $9.4 \%$ for $\mathrm{K}$ (Mills and Jones, 1996)] (data not shown). Leaf tissue $\mathrm{P}$ in fertilized lantana plants was lower than that in unfertilized plants, which might have been caused by a diluting effect of rapid plant growth under fertilization (data not shown).

FIRST-YEAR PLANT QUALITY. Visual quality ratings of all fertilized perennials were within the range representing "good" (8 to 9) to "excellent" (10) qualities at 5 MAT (Table 1). All species except purple coneflower fertilized with GF4 had similar VQ as those fertilized with GF2 (Table 1). Leaf greenness (measured as SPAD meter readings) responded positively to increasing GF rates for all species at 1 MAT (data not shown). Plants fertilized with GF4 had higher SPAD readings than plants fertilized with lower rates at 1 MAT (data not shown). By 5 MAT, positive responses were found for most species except lantana and rudbeckia (Table 1). However, no

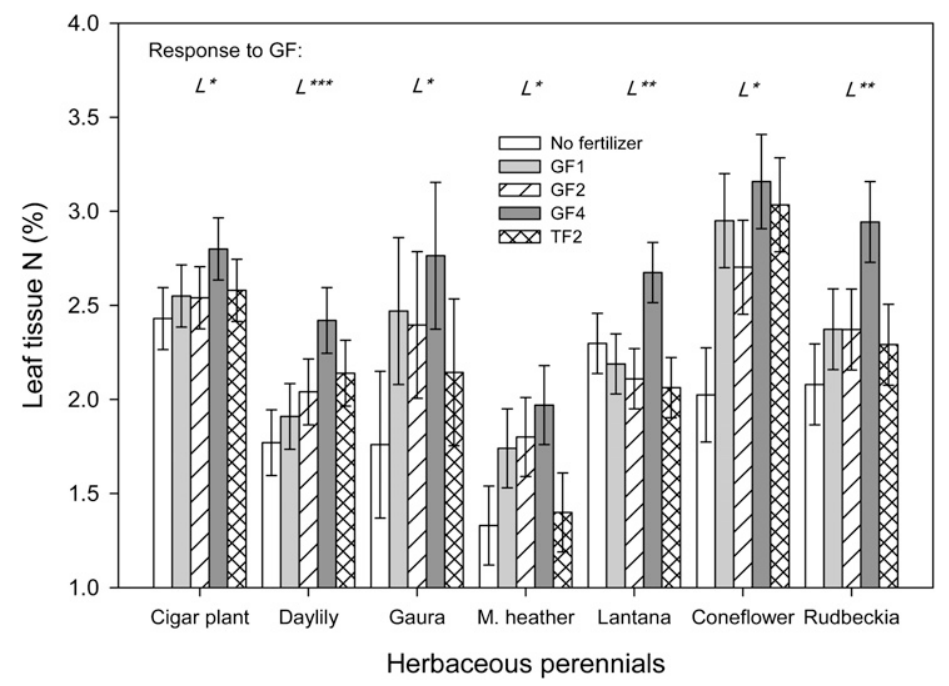

Fig. 2. Leaf tissue $\mathbf{N}$ concentrations of seven herbaceous perennials at $\mathbf{5}$ months after transplant into the landscape. Plants were fertilized with granular controlledrelease fertilizer (GF) $15 \mathrm{~N}-3.9 \mathrm{P}-10 \mathrm{~K}$ at $0,1,2$, and $4 \mathrm{lb} / 1000 \mathrm{ft}^{2}$ nitrogen [no fertilizer, GF1, GF2, and GF4 (1 lb/1000 ft $\left.\left.{ }^{2}=48.8243 \mathrm{~kg} \cdot \mathrm{ha}^{-1}\right)\right]$ or tablet fertilizer $16 \mathrm{~N}-3.5 \mathrm{P}-10 \mathrm{~K}[7.5 \mathrm{~g}(0.265 \mathrm{oz})]$ at two tablets per plant (TF2). Linear effects of GF rates on each perennial were tested via ordinary linear regression models using PROC REG of SAS with randomized complete block design ( * * *, and $* * *$ indicate significance at the $0.05,0.01$, or 0.001 level, respectively). Bars represent the least significant difference values $(\alpha=0.05)$ for pair-wise comparison of fertilizer treatments within each perennial; $M$. heather = mexican heather.

differences were found among fertilizer treatments in SPAD readings for all perennials except gaura (Table 1 ). This may indicate that the CRF had reached their later release stage by 5 MAT, with much less nutrients available for plant uptake. Laboratory studies indicate that the release rate of $\mathrm{N}$ is higher during the first half of the release period and decreases significantly after $40 \%$ to $60 \%$ of the $\mathrm{N}$ has been released, which is described as the "tailing effect" (Huett and Gogel, 2000; Newman et al., 2006). Consequently, plant growth may decrease during the latter half of the release period (Shaviv et al., 1994). Temperature also affects release rate (Cabrera 1997; Lamont et al., 1987) and Osmocote ${ }^{\circledR}$ Plus 8 to 9 month had a longevity of 5.5- and 4.5-month under 86 and $104^{\circ} \mathrm{F}$, respectively (Huett and Gogel, 2000). In this study, average daily temperatures from 1 May to 1 Oct. 2005 were 70 to $88^{\circ} \mathrm{F}$, thus a shorter release period was likely to occur. Diminishing nutrient supplies from the fertilizers may explain the lack of difference among GF rates in SPAD (and leaf tissue $\mathrm{N}$ concentration as well) in some of the perennials by 5 MAT.

Flowering performance was considered when assessing VQ and was evaluated specifically by flower counts over different flowering periods for daylily, gaura, purple coneflower, and rudbeckia and by FQ ratings for cigar plant, lantana, and mexican heather. Cigar plants had similar FQ regardless of fertilizer treatments (Table 1). Daylily plants fertilized with GF4 or TF2 had more flowers than plants fertilized with other treatments (Table 1). Although VQ of daylily plants fertilized with GF4 or TF2 at 1 and 5 MAT were similar to other treatments, these two fertilization rates will benefit flowering of 'Stella de Oro' daylily which blooms periodically from April to August (Odenwald and Turner, 2006). Purple coneflower fertilized with GF4 had more flowers than those fertilized with GF2, which may have contributed to its higher VQ with GF4 at 5 MAT (Table 1). A general trend with all species except rudbeckia was that plants fertilized with either TF2 or GF4 had similar number of flowers or FQ (Table 1).

Overwinter survival. Overwinter survival rate varied with perennials. All daylilies, no purple coneflower, and only a few rudbeckia plants survived 
Table 1. Overall plant visual quality (VQ), SPAD meter readings, and flowering performance of seven herbaceous perennials at $\mathbf{5}$ months after transplant into the landscape.

\begin{tabular}{|c|c|c|c|c|c|c|c|}
\hline Treatment $^{\mathrm{z}}$ & $\begin{array}{l}\text { Cigar } \\
\text { plant }\end{array}$ & Daylily & Gaura & Lantana & $\begin{array}{c}\text { Mexican } \\
\text { heather }\end{array}$ & $\begin{array}{c}\text { Purple } \\
\text { coneflower }\end{array}$ & Rudbeckia \\
\hline \multicolumn{8}{|c|}{ Overall plant VQ (1-10 scale $)^{y}$} \\
\hline No fertilizer & $5.7 c^{x}$ & 8.4 & $7.3 \mathrm{~b}$ & $7.8 \mathrm{~b}$ & $7.3 \mathrm{~b}$ & $4.3 \mathrm{c}$ & $6.4 \mathrm{~b}$ \\
\hline GF1 & $8.3 \mathrm{~b}$ & 9.0 & $9.0 \mathrm{a}$ & $9.4 \mathrm{a}$ & $9.4 \mathrm{a}$ & $8.2 \mathrm{~b}$ & $7.3 \mathrm{~b}$ \\
\hline GF2 & $9.0 \mathrm{ab}$ & 8.8 & $8.9 \mathrm{a}$ & $10.0 \mathrm{a}$ & $9.9 \mathrm{a}$ & $8.3 \mathrm{~b}$ & $9.2 \mathrm{a}$ \\
\hline GF4 & $9.9 \mathrm{a}$ & 9.1 & $9.4 \mathrm{a}$ & $9.1 \mathrm{a}$ & $10.0 \mathrm{a}$ & $9.4 \mathrm{a}$ & $10.0 \mathrm{a}$ \\
\hline \multicolumn{8}{|c|}{ SPAD meter readings } \\
\hline No fertilizer & 46.1 & 35.3 & $42.8 \mathrm{~b}$ & 29.1 & 36.3 & 39.3 & 37 \\
\hline GF1 & 39.1 & 38.5 & $47.4 \mathrm{~b}$ & 29.2 & 37.2 & 38.5 & 36.6 \\
\hline GF2 & 42.2 & 37.0 & $42.1 \mathrm{~b}$ & 27.6 & 33.5 & 42.1 & 35.0 \\
\hline GF4 & 43.6 & 39.5 & $40.3 \mathrm{~b}$ & 29.5 & 38.7 & 41.3 & 38.1 \\
\hline
\end{tabular}

Flower quality $(F Q)^{v}$ or total number of flowers or inflorescence ${ }^{u}$

\begin{tabular}{lccccccc}
\hline & $\begin{array}{c}\text { FQ } \\
(\mathbf{- 5} \text { scale })\end{array}$ & $\begin{array}{c}\text { Flower } \\
\text { (no.) }\end{array}$ & $\begin{array}{c}\text { Inflorescence } \\
\text { (no.) }\end{array}$ & $\begin{array}{c}\text { FQ } \\
(\mathbf{1}-\mathbf{5} \text { scale })\end{array}$ & $\begin{array}{c}\text { FQ } \\
(\mathbf{1}-\mathbf{5} \text { scale })\end{array}$ & $\begin{array}{c}\text { Flower } \\
\text { (no.) }\end{array}$ & $\begin{array}{c}\text { Flower } \\
\text { (no.) }\end{array}$ \\
\hline No fertilizer & 3.9 & $7.8 \mathrm{~b}$ & $51.6 \mathrm{~b}$ & $4.2 \mathrm{~b}$ & $3.1 \mathrm{~b}$ & $13.6 \mathrm{ab}$ & $16.6 \mathrm{c}$ \\
GF1 & 4.3 & $14.4 \mathrm{~b}$ & $107.6 \mathrm{a}$ & $4.4 \mathrm{ab}$ & $3.3 \mathrm{~b}$ & $12.8 \mathrm{~b}$ & $70.4 \mathrm{~b}$ \\
GF2 & 3.9 & $13.8 \mathrm{~b}$ & $98.4 \mathrm{a}$ & $4.6 \mathrm{a}$ & $3.9 \mathrm{ab}$ & $11.2 \mathrm{~b}$ & $48.3 \mathrm{bc}$ \\
GF4 & 4.2 & $25.2 \mathrm{a}$ & $130.3 \mathrm{a}$ & $4.5 \mathrm{a}$ & $4.3 \mathrm{a}$ & $30.6 \mathrm{a}$ & $147.0 \mathrm{a}$ \\
TF2 & 4.3 & $21 \mathrm{a}$ & $114.1 \mathrm{a}$ & $4.7 \mathrm{a}$ & $3.8 \mathrm{ab}$ & $25.6 \mathrm{ab}$ & $\mathbf{5 6 . 5 \mathrm { b }}$ \\
Linear effect & $\mathrm{NS}$ & $* * *$ & $* * *$ & NS & NS & $* *$ & NS \\
\hline
\end{tabular}

${ }^{2}$ Granular controlled-release fertilizer (GF) $15 \mathrm{~N}-3.9 \mathrm{P}-10 \mathrm{~K}$ at $0,1,2$, or $4 \mathrm{lb} / 1000 \mathrm{ft}^{2}$ nitrogen [no fertilizer, GF1, GF2, and GF4, respectively $\left(\mathrm{l} \mathrm{lb} / \mathrm{l} 000 \mathrm{ft}{ }^{2}=48.8243\right.$ $\left.\left.\mathrm{kg} \cdot \mathrm{ha}^{-1}\right)\right]$ or tablet fertilizer $16 \mathrm{~N}-3.5 \mathrm{P}-10 \mathrm{~K}$ at two tablets $[7.5 \mathrm{~g}(0.265 \mathrm{oz})]$ per plant $(\mathrm{TF} 2)$.

y $10=$ excellent, 8 to $9=\operatorname{good}, 6$ to $7=$ average, 4 to $5=$ below average, 2 to $3=$ poor, $1=$ dead

'Mean separation within columns and perennials by Tukey's significant difference test at $\alpha=0.05$. Means with the same letters are not significantly different.

"Linear effects of GF rates on dependent variables were tested via ordinary linear regression models using PROG REG of SAS. Randomized complete block design $(n=4)$. NS,

$*, *$, and $* * *$ indicate not significant and significant at the $0.05,0.01$, or 0.001 level of probability, respectively $(n=48$ for daylily and $n=32$ for other perennials).

$\checkmark 5$ excellent flower display with abundant flowers, 4 = good flower display, 3 = fair flower display, $2=$ some flowers, $1=$ scarce or no flowers.

"Total number of open flowers were the sum of flowers recorded from six sample dates for daylily and four sample dates for purple coneflower and Rudbeckia. Flower spikes in gaura plants were counted on one sample date.

(Table 2). Overwinter survival for cigar plant, lantana, and mexican heather were improved by some fertilization treatments (Table 2). Cigar plants fertilized with GF2, GF4, and TF2 exhibited higher overwinter survival rates than unfertilized plants and GFI and GF2-split treated plants (Table 2). Lantana fertilized with GF2 and TF2 had higher survival rates than unfertilized plants (Table 2). Mexican heather fertilized with GF4 survived better than those receiving no fertilizer or fertilized with GFl or GF2-split (Table $2)$. However, these results are preliminary because of the small sample size. Effects of fertilization on plant cold hardiness vary with different plant groups and both positive (Broschat, 2010; Webster and Ebdon, 2005), negative (Kelley, 1972), and no effects (Smiley and Shirazi, 2003) have been reported. Further research is needed to better understand the effect of fertilizer on the overwinter survival of herbaceous perennials.

Plant gRoWTH AND QUALITY AT 15 MAT. Fertilization affected SI and VQ of cigar plant and lantana but not that of daylily, gaura, and mexican heather by 15 MAT (Table 2). Cigar plants fertilized with GF4, GF2-split, and TF2 were similar in size and quality and larger than unfertilized plants. Lantana plants fertilized with GF4 had higher VQ than unfertilized plants with all fertilized plants having similar size and quality (Table 2). Compared with GF, TF2 resulted in similar growth and quality as GF4 for all species (Table 2).

Plants fertilized with GF2-split were similar in size and quality to those receiving other fertilization treatments at 15 MAT (Table 2). Split application of GF2 into spring and fall did not improve the overwinter survival of any species nor did it benefit the secondyear performance of any species compared with a single application in the spring. Thus, applying CRF in late summer was unnecessary to establish the perennials tested.

\section{Conclusion}

Daylily plants had similar acceptable VQ regardless of fertilization treatments throughout the experiment. Fertilized gaura, mexican heather, and lantana had better VQ than unfertilized plants by the end of the first growing season with similar acceptable quality among fertilized plants regardless of fertilizer type, rate, and timing, although GF4 and TF2 increased sizes of these perennials and improved flowering performance of daylily and mexican heather. Guara and lantana had relatively higher overwinter survival rates $(>63 \%)$ than other species with acceptable quality during the second 
Table 2. Overwinter survival, size index (SI), and overall plant visual quality (VQ) of herbaceous perennials successfully overwintered at 15 months after transplant into the landscape.

\begin{tabular}{|c|c|c|c|c|c|}
\hline Treatment $^{\mathrm{z}}$ & Cigar plant & Daylily & Gaura & Lantana & $\begin{array}{l}\text { Mexican } \\
\text { heather }\end{array}$ \\
\hline \multicolumn{6}{|c|}{ Overwinter survival (\%) $)^{y}$} \\
\hline No fertilizer & $25 b^{x}$ & 100 & 75 & $63 \mathrm{~b}$ & $25 \mathrm{~b}$ \\
\hline GF1 & $25 \mathrm{~b}$ & 100 & 75 & $88 \mathrm{ab}$ & $25 \mathrm{~b}$ \\
\hline GF2 & $75 \mathrm{a}$ & 100 & 63 & $100 \mathrm{a}$ & $50 \mathrm{ab}$ \\
\hline GF4 & $88 \mathrm{a}$ & 100 & 63 & $88 \mathrm{ab}$ & $75 \mathrm{a}$ \\
\hline GF2-split & $25 \mathrm{~b}$ & 100 & 88 & $88 \mathrm{ab}$ & $25 \mathrm{~b}$ \\
\hline TF2 & $75 \mathrm{a}$ & 100 & 88 & $100 \mathrm{a}$ & $38 \mathrm{ab}$ \\
\hline \multicolumn{6}{|c|}{$S I(\mathrm{~cm})^{w}$} \\
\hline No fertilizer & $21.0 \mathrm{c}$ & 40.2 & 42.4 & $58.4 \mathrm{~b}$ & 22.9 \\
\hline GF1 & $24.3 \mathrm{bc}$ & 42.2 & 43.2 & $67.8 \mathrm{ab}$ & 26.2 \\
\hline GF2 & $34.1 \mathrm{bc}$ & 40.9 & 46.6 & $73.4 \mathrm{ab}$ & 32.4 \\
\hline GF4 & 59.9 a & 44.9 & 45.5 & $82.2 \mathrm{a}$ & 34.8 \\
\hline GF2-split & $42.0 \mathrm{ab}$ & 45.9 & 40.3 & $76.1 \mathrm{a}$ & 24.7 \\
\hline TF2 & $41.0 \mathrm{ab}$ & 41.6 & 42.0 & $74.5 \mathrm{ab}$ & 33.9 \\
\hline \multicolumn{6}{|c|}{ Overall plant VQ (1-10 scale $)^{v}$} \\
\hline No fertilizer & $4.5 \mathrm{~b}$ & 8.8 & 8.0 & $6.7 \mathrm{~b}$ & 4.0 \\
\hline GF1 & $4.0 \mathrm{~b}$ & 9.0 & 8.5 & $8.1 \mathrm{ab}$ & 3.0 \\
\hline GF2 & $6.1 \mathrm{~b}$ & 8.8 & 9.6 & $8.1 \mathrm{ab}$ & 6.0 \\
\hline GF4 & $9.6 \mathrm{a}$ & 9.0 & 8.8 & $8.6 \mathrm{a}$ & 7.8 \\
\hline GF2-split & $9.0 \mathrm{ab}$ & 9.4 & 8.4 & $8.0 \mathrm{ab}$ & 4.0 \\
\hline TF2 & $8.0 \mathrm{ab}$ & 8.5 & 8.3 & $8.1 \mathrm{ab}$ & 9.0 \\
\hline
\end{tabular}

${ }^{\mathrm{z}}$ Granular controlled-release fertilizer (GF) $15 \mathrm{~N}-3.9 \mathrm{P}-10 \mathrm{~K}$ at $0,1,2$, or $4 \mathrm{lb} / 1000 \mathrm{ft}^{2}$ nitrogen [no fertilizer, $\mathrm{GF} 1, \mathrm{GF} 2$, and GF4, respectively $\left.\left(1 \mathrm{lb} / 1000 \mathrm{ft}^{2}=48.8243 \mathrm{~kg} \cdot \mathrm{ha}^{-1}\right)\right]$ or tablet fertilizer $16 \mathrm{~N}-3.5 \mathrm{P}-10 \mathrm{~K}$ at two tablets $[7.5 \mathrm{~g}(0.265 \mathrm{oz})]$ per plant (TF2).

y Overwinter survival rate (\%) was calculated for each perennial in each plot.

${ }^{x}$ Mean separation within columns and perennials by Tukey's significant difference test at $\alpha=0.05$. Means with the same letters are not significantly different.

w (plant height + widest width + perpendicular width $) / 3 ; 1 \mathrm{~cm}=0.3937$ inch

v $10=$ excellent, 8 to $9=$ good, 6 to $7=$ average, 4 to $5=$ below average, 2 to $3=$ poor, $1=$ dead

growing season regardless of fertilizer type, rate, and timing. For these two species, TF2 or GF1 will improve growth and quality during their first growing season with minimum use of fertilizer.

Optimum quality was obtained with GF2 or GF4 for cigar plant by the end of the first growing season (Table 1) and with GF4, GF2-split, or TF2 during the second growing season (Table 2). Because TF2 resulted in acceptable quality for the first growing season and higher overwinter survival rate, we recommend TF2 for cigar plant.

Although none of the purple coneflowers and few rudbeckia plants overwintered, better quality was obtained with GF4 or TF2 for purple coneflower, and GF2, GF4, or TF2 for rudbeckia for the first growing season. Therefore, TF2 is recommended for these two species.

Overall, TF2 resulted in similar plant size as GF2 for all perennials and similar quality as GF4 for all perennials except cigar plant by the end of the first growing season (5 MAT), and similar plant size and quality as both GF rates for perennials returned in the second year (15 MAT). On the basis of these results, we recommend applying two tablets of $16 \mathrm{~N}-3.5 \mathrm{P}-10 \mathrm{~K}$ ( $7.5 \mathrm{~g}, 8$ to 9 month) for all the perennials tested in this study, which uses about the same amount of fertilizer as GFl for an $80-\mathrm{ft}^{2}$ landscape bed area with a planting density of 15 plants per area.

When attempting to group nutrient needs of tested perennials by their size or biomass, apparently larger plants may gain more growth under higher fertilization rates such as GF4 but not necessarily better quality. Further research will be needed to determine the effects of CRF application on the overwinter survival of herbaceous perennials, and the appropriate uses of CRF for various soil profiles to enhance nutrient use.

\section{Literature cited}

Alva, A.K. 1992. Differential leaching of nutrients from soluble vs. controlledrelease fertilizers. Environ. Mgt. 16:769776.

Barker, A.V. and G.M. Bryson. 2007. Nitrogen, p. 2243. In: A.V. Barker and D.J. Pilbeam (eds.). Handbook of plant nutrition. CRC Press, Boca Raton, FL.

Berry, C.R. 1983. Growth response of four hardwood tree species to spot fertilization by nutrient tablets in the Tennessee Copper Basin. Reclamation Revegetation Res. 2:167-175.

Beverly, R.B., W. Florkowski, and J.M. Ruter. 1997. Fertilizer management by landscape maintenance and lawn care firms in Atlanta. HortTechnology 7:442-445.

Broschat, T.K. 1995. Nitrate, phosphate, and potassium leaching from containergrown plants fertilized by several methods. HortScience 30:74-77.

Broschat, T.K. 2001. Development of an effective fertilization program for palms and other tropical ornamental plants in south Florida landscapes. Res. Rpt. 200101. Univ. Florida Inst. Food Agr. Sci., Fort Lauderdale, FL.

Broschat, T.K. 2010. Fertilization improves cold tolerance in coconut palm. HortTechnology 20:852-855.

Brown, C.A. 1976. Wildflowers of Louisiana. Louisiana State Univ. Press, Baton Rouge, LA.

Brown, S.P. 2007. Perennial gardening in Florida. Univ. Florida Inst. Food Agr. Sci. Ext. Pub. ENH-68.

Cabrera, R.I. 1997. Comparative evaluation of nitrogen release patterns from controlled-release fertilizers by nitrogen leaching analysis. HortScience 32:669-673.

Cabrera, R.I. and H.B. Pemberton. 2007. Greenhouse rose productivity and nutrient status in response to fertilization with a controlled-release fertilizer. Acta Hort. 751:77-82.

Cox, D.A. 1993. Reducing nitrogen leaching-losses from containerized plants: The effectiveness of controlled-release fertilizers. J. Plant Nutr. 16:533-545.

Florida Yards \& Neighborhoods. 2006. A guide to Florida-friendly landscaping: Florida yard \& neighborhoods program. Univ. Florida Inst. Food Agr. Sci., Gainesville, FL.

Gilman, E.F. and T.H. Yeager. 1990. Fertilizer type and nitrogen rate affects field-grown laurel oak and Japanese ligustrum. Proc. Florida State Hort. Soc. 103: 370-372. 
Gilman, E.F., T.H. Yeager, and D. Kent. 2000. Fertilizer rate and type impacts magnolia and oak growth in sandy landscape soil. J. Arboriculture 26:177-182.

Gray, L.N. and G.J. Rose. 1968. An American approach to feeding containergrown plants and trees. Commercial Grower 3769:675-677.

Greenwell, B.R. 1982. Use of Osmocote in container growing. Comb. Proc. Intl. Plant Prop. Soc. 85-88.

Halbrooks, M.C. 1990. Nutrition of container and field-grown nursery crops. Clemson Univ. Coop. Ext. Serv., Ext. Bul. 138.

Hatchell, G.E. and D.H. Marx. 1987. Response of longleaf, sand, and loblolly pines to Pisolithus ectomycorrbizae and fertilizer on a sand hill site in South Carolina. Forest Sci. 33:301-315.

Huett, D.O. and B.J. Gogel. 2000. Longevities and nitrogen, phosphorus, and potassium release patterns of polymercoated controlled-release fertilizers at $30^{\circ} \mathrm{C}$ and $40^{\circ} \mathrm{C}$. Commun. Soil Sci. Plant Anal. 31:959-973.

Ingram, D.L. and T.H. Yeager. 1985. Influence of compressed fertilizer tablets containing sulfur and growth medium amendments of dolomitic limestone and superphosphate on nutrient release and azalea growth. Proc. Florida State Hort. Soc. 98:139-142.

Israel, G.D., S.B. Pinheiro, and G.W. Knox. 1995. Environmental landscape management: Assessing practices among commercial groups. Univ. Florida Inst. Food Agr. Sci., Gainesville, FL.

Jacobs, D.F., K.F. Salifu, and J.R. Seifert. 2005. Growth and nutritional response of hardwood seedlings to controlled-release fertilization at outplanting. Forest Ecol. Mgt. 214:28-39.

Juntunen, M.L., T. Hammar, and R. Rikala. 2003. Nitrogen and phosphorus leaching and uptake by container birch seedlings (Betula pendula Roth) grown in three different fertilizations. New Forest 25:133-147.

Kelley, J.D. 1972. Leaf nitrogen and winter hardiness of Pyracantha coccinea 'Lalandi' and Ilex crenata 'Rotundifolia'. J. Amer. Soc. Hort. Sci. 97:446-448.

Kelly, L. and S.E. Newman. 2007. Annual and perennial flowers for Mississippi gardens. Mississippi State Univ. Ext. Serv. Pub. 1826.
Kessler, J.R., Jr., J.D. Williams, and B. Clendenen. 2002. Herbaceous perennials in Alabama. Alabama Coop. Ext. Serv. Pub. ANR-566.

Klock-Moore, K.A. and T.K. Broschat. 1999. Differences in bedding plant growth and nitrate loss with a controlled-release fertilizer and two irrigation systems. HortTechnology 9:206-209.

Kuhns, L.J. 1987. Fertilizing woody ornamentals. Pennsylvania State Univ. Coop. Ext. Serv. Circ. 353.

Lamont, G.P., R.J. Worrall, and M.A. O'Connell. 1987. The effects of temperature and time on the solubility of resincoated controlled-release fertilizers under laboratory and field conditions. Sci. Hort. $32: 265-273$.

Louisiana State Univ. Agr. Ctr. 2005. Louisiana Agriclimatic Information System. $<$ http://weather.lsuagcenter.com/>.

Louisiana Yards \& Neighborhoods. 2007. A guide to Louisiana-friendly landscaping-Louisiana yards and neighborhoods program. Louisiana State Univ. Agr. Ctr., Baton Rouge.

Mills, H.A. and J.B. Jones. 1996. Plant analysis handbook II. A practical sampling, preparation, analysis, and interpretation guide. MicroMacro Publishing, Athens, GA.

Neal, C. 2003. Slow-release fertilizers for home gardens and landscapes. Univ. of New Hampshire Coop. Ext. Rpt. No. 516.

Newman, J.P., J.P. Albano, D.J. Merhaut, and E.K. Blythe. 2006. Nutrient release from controlled-release fertilizers in a neutral-pH substrate in an outdoor environment: I. Leachate electrical conductivity, $\mathrm{pH}$, and nitrogen, phosphorus, and potassium concentrations. HortScience 41: 1674-1682.

Odenwald, N.G. and J.R. Turner. 2006. Identification, selection, and use of southern plants for landscape design. 4th ed. Claitor's Publishing, Baton Rouge, LA.

Proctor, C.L., S.L. Warren, R.L. Mikkelsen, D.J. Werner, and H.T. Kraus. 2004. Effect of nitrogen rate and nitrogen timing on herbaceous perennials in a simulated landscape. Proc. Southern Nursery Assn. Res. Conf. 49:441-445.

Rose, M.A. 1999. Nutrient use patterns in woody perennial: Implications for increasing fertilizer efficiency in field-grown and landscape ornamentals. HortTechnology 9:613-617.

Sato, S. and K.T. Morgan. 2008. Nitrogen recovery and transformation from a surface or sub-surface application of controlled-release fertilizer on a sandy soil. J. Plant Nutr. 31:2214-2231.

Shaviv, A., O. van Cleemput, G. Hofman, and A. Vermoesen. 1994. Plant response and environmental aspects as affected by rate and pattern of nitrogen release from controlled-release fertilizers. Univ. of Ghent, 5-8 Sept. 1994. Proc. 8th Nitrogen Wkshp: 285-291.

Shaviv, A. and R.L. Mikkelsen. 1993. Controlled-release fertilizers to increase efficiency of nutrient use and minimize environmental degradation-A review. Fert. Res. 35:1-12.

Shober, A., C.D. Geoffrey, and T.K. Broschat. 2010. Management of fertilizers and water for ornamental plants in urban landscapes: Current practices and impacts on water resources in Florida. Hort Technology 20:94-106.

Smaal, A. 1984. Osmocote controlled release fertilizer. Proc. 6th Intl. Congr. Soilless Cult.: 595-598.

Smiley, E.T. and A.M. Shirazi. 2003. Fall fertilization and cold hardiness in landscape trees. J. Arboriculture 29:342-346.

Strother, E.A., S.A. Cheatham, P.A. Rollins, and S.N. Jeffers. 2002. Evaluation of 30 herbaceous perennial plants for low maintenance landscapes in South Carolina. Proc. Southern Nursery Assn. Res. Conf. 47: 484-491.

Torres, K.C. 1987. Controlled-release fertilizers effect on the growth of bed-grown woody landscape plants. HortScience 22: 1330 .

Webster, D.E. and J.S. Ebdon. 2005. Effects of nitrogen and potassium fertilization on perennial ryegrass cold tolerance during deacclimation in late winter and early spring. HortScience 40:842849.

Yeager, T.H., R.D. Wright, and M.M. Alley. 1980. Response of Ilex crenata Thunb. cv. Helleri to timed fertilizer applications. Response of Ilex crenata Thunb. cv. Helleri to timed fertilizer applications. J. Amer. Soc. Hort. Sci. 105: 213-215. 